\title{
Child Speech Development at Pre-school and at School: Aspect of Successive Learning
}

\section{Abstract}

Whilst living in today's contemporary and diverse environment of visual information, people draw too little attention to verbal information, textual perception, listening, reading and writing. However, language is not only a means of communication. Language is also a means of acknowledging human thinking, self-affirmation and ethnicity. Since the main goal of education is to raise a creative personality, the mutual relationship between language and speech becomes the most important means to this end.

In order to effectively address children's speech development issues within the pedagogical process at pre-school and at school, one must be aware of the necessity for an individual approach to each child, as the levels of their speech development differ. The causes of this might be found in our current socio-economic environment, in which a child grows and develops. Speech development of a child is closely related to his or her upbringing as a personality. As early as at pre-school, a child needs to learn to control and to manage his or her behaviour, to be able to listen, to perceive the meaning of what he or she has heard and to act accordingly, to observe certain rules and to precisely and consistently obey to the cultural norms of a listener and a speaker. A child needs to acquire the skill to concentrate his or her attention, to make observations of the surrounding environment, to narrate the seen and the heard, to perceive objects, to compare and to contest them, to question, to answer, to conclude, to be able to recognize a word that has been used to signify an object, an event or a process, to understand its meaning in a specific context, to recognize the phonetic qualities of a word, to analyze the sounds in the word, etc. The aforementioned qualities are further developed at school level by deepening the contents and form. As pre-school children and early school age children perceive the world in an emotional way, a positive emotional context is important for a positive speech development. This process requires a kind of study content and a methodological provision that links a child's associations to his or her experience. During the period of pre-school and early school a child may experience difficulty to concentrate, especially if a child is not interested in the study contents, if the contents are vague and do not stimulate thinking. The more complex thought operations a child has to employ in the process of speech development, the more complete and precise his or her speech becomes. Since at pre-school and at early school ages a child is not result-driven psychologically, it is important to ensure an educational process, in which, by successively and playfully 
passing from one action to another, a child indirectly acquires speech and experiences positive emotions as a response to his or her achievements.

Key words: language, speech, successive learning

\section{Introduction}

In comparison to the previous century, in the 21st century increasingly more visual means are used to reflect the surrounding world: images, drawings, and various symbols that provide information in an interesting and attractive form. This kind of information attracts attention and generates interest. Psychologically people perceive visually driven information much faster than written information. Visual information may also suppress verbal information, as a visually perceived image is more powerful and is memorized for a longer period of time. At the same time, visually represented information has a higher probability of subjective interpretation, since each person may perceive and understand the visual image differently (Sousa, 2001). Yet, verbally expressed information, if it is conveyed precisely and supported with sub-linguistic means (gestures, mimicry, voice modulation, speech tempo, pauses etc.), is much more precise and presents the aim of a speaker or a writer in a more clear manner. Simultaneously it is important to understand that language is not only a means of communication, but also a means of acknowledging human thinking, self-awareness and ethnicity.

Living in our contemporary multicultural society, it is particularly important for people to understand each other and to remain tolerant in communication. One of the most important skills to be acquired during the pedagogical process is knowledge of language that includes a capacity to engage in speech activity according to the communicational situation and to one's own goals, a level of language knowledge and techniques that enable to use the acquired language in focused speech, as well as in listening, reading and writing (Lingvodidaktikas terminu skaidrojošā vārdnīca 2011, 98). In approaching a child's language as a system of signs and speech as an expression of this system in various stages of a child's life, it should be noted that this is a gradual and successive process, related to such psychic processes as perception, attention, memory, thinking, as well as socioeconomic aspects of the prevalent culture, in which a child grows and develops. The most important aspect in language perception is the specificity of a child's hearing, sight and memory development. For a child language is constituted by everything that takes place around him or her - that, which can bee seen, felt or heard. As much as thinking, language, too, is linked to individual experience. Language and speech develops along with an enrichment of a child's views; in other words, the limits of language are the limits of the world (Svence, 2011).

Since nowadays the main goal of education is to educate people, who can create something new, rather than repeat what has already been done by previous generations, as well as to nurture people with critical minds, with a capacity to test 
things before accepting them as truths (Piažè, 2002), language and speech in their correlation turn out to be one of the most significant means for this end.

\section{Aim of the study}

To draw attention to various aspects of development and successive learning of a child's speech at pre-school and at early school age, when a child consciously, gradually and in a correlated way starts to learn all aspects of the speech act: the skill to listen and to talk, the skill to read and to write.

\section{Materials and methods}

The article uses findings in speech development from scientists of various countries in the fields of psychology and pedagogy, taking into account child development trends within the current social context at pre-school and at early school age. In the context of the research problem, the article analyzes the observations of partnership between pre-school and early school age children and their teachers within the pedagogical process, as well as the experience acquired when working with students, who study to become pre-school and primary school teachers at the Riga Teacher Training and Educational Management Academy (RTTEMA) and with pre-school and school teachers of further education programmes.

\section{Results and discussion}

In order to purposefully address questions of successive learning in child speech development within the pedagogical process at pre-school and at early school age, it is important to understand that the didactical principle of successive learning requires taking into account the previous experience and ensuring a gradual acquisition of the new experience, by moving from the known to the unknown and from the easy to the difficult. A precisely diagnosed situation is a prerequisite for this. This ensures the right choice of the contents of language and speech development as well as its methodological application.

According to the research of psychologists and pedagogues, every child has a peculiar experience in speech use, acquired since birth, in an informal, everyday family context, as well as outside of it. If the setting for a child's speech development has been right and there are no observable language and speech disorders, then already at the age of three a child is able to perceive what he or she hears and to reproduce it. At the age of four - yet predominantly at ages five and six - a child has a level of speech development that enables him or her to express feelings and needs. At this age a child has developed a phonemic perception (a capacity to distinguish between perceptible sounds), has a sufficient vocabulary and a skill to put words into full sentences, to form statements appropriate to the particular communication situation. Having reached school age, a child can perceive and 
pronounce all of the sounds in one's native language. A child has developed an understanding of the morphologic and syntactic aspects of language - a skill to correctly use words according to gender, number, case, and has basic knowledge in word-formation (creation of new words by means of prefix, suffix together with the ending, as well as formation of compound words). At this age a child can regulate the tempo and the tone of speech, use various intonations depending on the type of sentence and the aim of the utterance. In communication a child uses a sufficiently wide range of simple extended sentences and composite sentences. These prerequisites enable a child to use speech in increasingly diverse situations - to tell or to retell an event, a story etc. In narration a child is able to show a logical exposition. Furthermore, if during earlier stages, to observe a particular sequence of events, a child needed to have an example to be guided by (a precise retelling of the contents of a story, answering questions following the example of adult speech etc.), then already at ages six and seven a child can compose creative narratives without a set example, for instance, to compose fairytales or to create a narrative plot on the basis of an image. At pre-school and early school age there is a gradual shift from an adult-guided to an independent narration. Already at the age of five a child enters the so-called 'librarian age' with an increased interest in everything written in books, magazines or other information sources. At this age a child can analyze the actions of adults fairly well. A child is aware that in the adult world communication and acquisition of new experience takes place through language. (Svence, 2011; Nichols, Rupley, Rasinski, 2009; Абрамова, 2002; Sousa, 2001 ).

By improving own speech skills, a child awaits to see an achievement in this respect. If he or she does not see a point in doing these tasks, if the acquisition of new things is not based on previous experience, there comes frustration since the expectations have not delivered a lasting satisfaction. In this stage a child feels disappointed, becomes stressed, experiences inner anxiety that often leads to isolation, protest and reluctance to speak, and later, possibly, a refusal to read and write. This is especially dangerous during pre-school and early school age, when learning a language as a meaningful process has just begun. It is at this age that a child discovers the world and learns to live in it physically, emotionally and socially. For this reason during the speech development process the choice of learning contents as well as the teaching methodology and the achievement assessment system must be well thought through (Anspoka, 2011).

To ensure successive speech development of a child, one must first get to know a child and take into consideration contemporary social development tendencies in and peculiarities of the environment, in which a child grows and develops. Since society regularly undergoes changes, speech development of a child at pre-school and at early school age becomes increasingly complicated. Data obtained during observations of the pedagogical process enable us to conclude that at pre-school and later in school every child needs individual attention, since each child is at a 
different level of speech development. Reasons for that might be sought in our socio-economic environment. Not only do children develop in different cultural environments - there are also differences in the ways their brain hemispheres operate, in their skills, worldviews and values. It is also important to note the increasing differences between girls and boys of the same age in their perception of the surrounding world, and, consequently, their attitudes towards it (Абрамова, 2002, Крайг, 2000).

Up until pre-school in many families a child has not been trained to consciously listen and to perceive information. According to the observations of teachers, at least half of parents do not read fairytales and stories to their children or engage in dialogue formation with them through play. Topics of conversation generally cover mundane issues such as food, clothing, tidying up, etc. In such conversations children manage to use a minimal amount of phrases or only facial expressions and gestures. Children lack vocabulary as well as a skill to form meaningful sentences from the words that they know, covering topics like nature, events in the surrounding world, expressing their attitude towards the seen, the heard or the experienced. Often this is the cause of the minimal differences in the level of speech development between four- and six-year-olds (on the condition that sixyear-olds have not attended pre-school before the age of five) (Svence 2011)

Nowadays children are also more socially active. There are several reasons for this. In the family context, children either lack stability and therefore attention or, due to various circumstances, such as travelling or extracurricular activities, children have acquired a lot of additional information that they wish to share with their peers at pre-school or at school, striving to be noticed and recognized. If a teacher does not recognize this need, a child becomes accustomed to speaking carelessly, without planning or controlling own speech, or the contrary - a child shrinks into him- or herself, does not engage in conversation, or more or less consciously disturbs others.

The means of information and the ways of its perception have also become diversified. A TV set, a personal computer, a mobile phone and toys with special computer software also influence the development of a child. Working with information and communication means predominantly facilitates the development of rational thinking, however, it does not advance emotional development. Children often lack socialization with other people. As a result, children often lack the experience of listening, perceiving information and acting accordingly. Furthermore, children do not understand the emotional undertones in texts, sentence intonations or the multiple meanings of words found in various social contexts (Sousa, 2001). Since ever more children watch cartoons, TV commercials, videos, all dominated by musical and visual rather than verbal effects, they lack a vocabulary to express their attitude to what they have seen or heard (Svence, 2011). 
Modern day civilization does not allow children to be fully in touch with nature either. Walks in the park instead of walks in the woods or meadows, where objects of nature may be encountered directly, does not encourage complete activation of a child's senses or his or her emotional development (Абрамова, 2002; Sousa, 2001). As teachers and recent RTTEMA graduates of the Bachelor's study program "Pre-school and Primary School Teacher" observe during their internships, children of pre-school and early school age lack vocabulary to express their thoughts in an emotional way, as they simply cannot perceive the meaning of words expressed in folk songs, fairytales or literature, and even less so if they are used figuratively.

The observations above allow us to conclude that the process of a child's speech development is simultaneously a process of upbringing a child as a personality. As early as at pre-school, it is important that a child learns to control and manage own behaviour, learns to listen, to perceive the meaning of what is seen or heard and initially to act on it accordingly through speech, to observe certain rules, to overcome difficulties, if they arise, to finish the work on time, to precisely and consequently observe elementary cultural norms of speaking and listening, to acquire the skill to concentrate attention, to observe the surrounding world, to talk about what has been heard or seen, to perceive objects, to compare them, to contradistinguish them, to ask questions, to give answers, to make conclusions, etc., to be able to perceive the word used to name an object, an event or a process, to understand its meaning in the specific context, to listen to the sound of the word, to analyze sounds in the word, etc. (Anspoka, 2011).

By continuing to study, a child continues to learn to concentrate attention, will, perception and a skill to hear what is being read and to perceive that, what is written, to use senses to translate the incoming signals into forms of thought or emotion, to compare them with forms that exist in the memory, to understand the implicit meaning and to draw conclusions in a symbolic form. Symbolic communication is a way, by means of which a child learns to create a link between the internal and the external world, to influence or change the surrounding world according to the I-Conception (Svence, 2011; Крайг, 2000).

Speech development includes a purposeful exploration of the surrounding world, and finding one's own place in this world. Whether at pre-school or at early school age, each child first of all has the need to find out the correlation between things and phenomena, the need for interacting with people, the need to be active, the need to imagine, to fantasize, to see the results of own work and to be recognized. This means that a child at pre-school or at school age should be taught to use language as a means of thought. A child needs to learn that language expresses cultural traditions of a particular ethnos, habits, peculiarities of the everyday lifestyle, as well as emotions. When a child realizes that words represent the world he or she inhabits, it is easier for a child to perceive what he or she hears, reads or writes. Working with words and stating them, or subsequently reading or writing 
them, a child learns to recognize concrete things or phenomena behind them, to discover the causalities between these things and phenomena. By learning about the world of words, a child also learns about the real world - the one that he or she inhabits, and the one that can be discovered only through books, stories, fairytales, beliefs or folk songs. The more diverse the verbal world of a child, the more a child is able to orient him- or herself and act in the real world (Gavrilina, Vulāne, 2008). By working with a word in a certain context, a child simultaneously develops in his or her concrete, figurative and verbally logical thinking. Figurative thinking gradually turns into abstractly logical thinking and this is directly linked to a conscious use of language and such thought operations such as synthesis, analysis, comparison, generalization, development and improvement. (Sousa, 2001; Выготский, 1997). At pre-school and early school age it is difficult to focus if the learning contents are not of interest, if the process is abstract and does not stimulate thinking. The more complex thinking operations a child uses during the speech development process, the more complete and precise will a child's language and speech become.

From the perspective of successive learning it is not acceptable that at preschool and early school age different approaches are chosen in the development of a child's personality and language acquisition. Analysis of the pedagogical process in various educational institutions in Latvia enables to draw conclusions that at preschool a child develops language holistically within the communicative approach, while as a child continues education at school, the acquisition of language takes place within a structural approach within a system of separate subject learning, in which the structure of language and its particular elements is learned in a systematized way. This approach does not allow maintaining successive language acquisition and a chance for each child to develop language according to own capacities and needs. At pre-school and at early school age it is important not to simply teach the language, but, through working creatively, to introduce a child to the world of language sounds, words and sentences, in which a child discovers various events linked to his or her life or the life of others, as well as an attitude towards these events. Nowadays in educating a child at pre-school and at early school age a preference should be given to the communicative approach. This, of course, does not mean that within this the acquisition of cultural norms of a listener, talker, reader or writer become less important. Within linguistic didactics there are various opportunities of how to use the communicative approach to help a child to acquire such skills. Working with sentences and words in a meaningful text, without separating meaning and form, should become a kind of a play or a game, resulting in joyous activity of a child not only at pre-school, but also at school.

In this regard the way a certain study subject is formulated, becomes important. The less experience children have in using speech in specific communication situations, the more the subject needs to foster a child's thinking, create associations with a child's own, however small, experience. Internship analysis and completion 
of independent tasks of teachers in further education programmes show that often the topics of study at pre-school and early school language programmes and language lesson plans are often formulated as: "Autumn", "Friendship", "Christmas", "Easter" etc. Firstly, formulations of this kind are too broad. They do not train a child to think in a precise way and to use specific language means to express a thought. Secondly, it is impossible to ensure a gradual and systematic discovery of the surrounding world. Repetition, if it is not purposefully deepened, in itself does not guarantee a better and deeper understanding of the necessary information. Quite the contrary, only information increasingly rich in form and contents stimulates speech development. If that is not the case, there might be a contrary effect - language and speech development of a child may stop. At the same time a child becomes accustomed to superficiality in thinking and in expression of own judgements by means of language. In this regard observations from the field suggest that this requires a greater precision from a teacher in planning the structure of a lesson or a game-lesson. This is especially the case if a teacher has decided to implement thematic integration that foresees acquisition of learning contents of separate subjects, including the subject of language, by means of choosing a common theme. Integrated learning does not free a teacher from responsibility to help a child to successively acquire systematic language learning contents. It only requires the use of types of controlled speech acts in order to realize a particular educational aim. In practice it is not permissible to mix up a lesson and a game-lesson as a form of study organization with a game or a play in the sense of methodological means in the speech development process. A game and a play are to be used in both stages of learning, if only they fit the specific goal of study.

Since at pre-school and at early school age a child perceives the world emotionally, it is games and playing that create a positive, free and natural emotional background. With their diverse functions games and play become the means of a child's education and upbringing. The more time a child spends with a teacher or with his or her peers in play or games, which require speaking, the quicker a child learns to react to a specific situation, such as choosing the right kind of expression. A game is also important for the development of a child's physical and mental capacities - attention, resourcefulness, will, courage and dexterity. It is precisely in game that the life of a child flows more naturally. A game is a form of organizing a child's life, in which certain mutual relationships develop, feelings and an attitude to the processes are expressed (Dzintere, Stangaine, 2007; Новикова, 2006). A positive study environment also ensures that important psychological needs are met - emotional and physical safety, close, mutually favourable relationships, independence, an opportunity to participate in the study process, as well as a conviction that own knowledge is useful to others. Every child needs to have confidence that in case of a necessity each one of them would be supported 
and encouraged. Every child needs to experience that his or her thoughts are important and significant to others, even if, for the time being, they are expressed in imprecise and incorrect language, as that, which is incorrect from a grammatical point of view, is valuable at the level of thinking.

Nowadays it is important that children are in touch with nature. Lessons indoors, with previously prepared natural materials should be supplemented with outdoor classes. Sight and hearing in connection to touch, smell and taste foster the brain activity of a child, development of small hand muscles, especially the responsiveness of fingers, which, in turn, is directly related to the development of the articulation apparatus. Finger training facilitates the development of a child's speech and his or her intellectual development, helps to self-regulate own actions during the writing process. Being in touch with nature broadens a child's vocabulary and provides experience in using words according to a particular situation.

Imitative actions play an equally important role in speech development. The joy that a child experiences by initially only listening to an expressive reading or by seeing a written text and, subsequently, by imitating this process, is the first serious step on the way to acquiring good language skills. Purposefully planned game-lessons at pre-school and at school are aimed at letting a child to get used to perceiving statements within a text, to learn to distinguish certain words in hearing and later on, as a child learns to read and write, to read them with an appropriate intonation, if necessary to emphasize specific words in a text, to pay attention to capital letters and punctuation at the end of sentences, text formatting etc. Study tasks of this kind gradually accommodate children to perceive and to understand that in the process of communication both verbal and non-verbal means are important (intonation, emphases, pauses, mimicry, gestures, the flow of speech during reading, bodily position, movement of arms during the writing process, etc). At times more can be gained from hearing and observation than from own self-expression or, for that matter, from mistaken actions (Амонашвили, 2011; Anspoka, 2011).

In order to encourage a child's belonging to a certain cultural environment in the global world of today, and simultaneously, to gradually teach a child to express his or her identity, the research activities of children at pre-school and at school should be broadened. It is only by researching the local toponyms and other geographical names, their origins, names of people, by reading legends and fairytales that are linked to historical events and people of specific locations, that a child can better perceive the information carried within a language and understand that language helps discover the ethnos as well as the culture of each individual. Such an approach, of course, necessitates great professional courage from a teacher not to be afraid of the principles of such a forward thinking educational approach, which requires to include into the study process such subjects and methods of teaching and study organization forms that demand more focus from children as well as a need to train their associative memory. 
At the same time a teacher should not worry if one of the children cannot complete a particular learning task. Instead a teacher should simply remain patient, waiting for a child to answer, as time or even a moment of silence is required to find the most adequate words to express own thoughts. In order to help a child overcome the period of silence and to stimulate a child's speech and thinking, a teacher may use supplementary help (key words, unfinished sentences, separate words, drawings, a narrative plan, etc).

Given that speech development directly depends on the possibilities of each individual to apply these in practice in a variety of natural communication situations, a teacher should not exaggerate his or her own role as a speaker. This requires patience on behalf of a teacher, as well as specific pedagogical tools, so that a child has an interest to ask questions, to give answers, to tell stories, by using specific words in order to express own thoughts.

Nowadays information technologies also are a great help in the process of a child's speech development. Specially prepared digital learning materials, if used purposefully, enable to use senses (sight, hearing, touch, movement etc.), based on which associations with previously obtained experience are created. The use of digital learning materials raise a child's activity, as a child sees that, just like the adults, he or she, too, can obtain information by reading or can pass it on to others in writing. Computer programmes provide an opportunity to compare objects, names, to group them according to various characteristics, to move them around, to combine, to separate, to shrink or to enlarge them, to colour or to mark them, to write, to edit or to check the results of work, to evaluate and listen to records or to record own speech, to add interactive online resources, etc. It should also be noted that working with a computer also develops the small hand muscles. Certainly, just like we pay attention to the way a child sits by the table and holds a pen during writing, we should also pay attention to a child completing computer-based learning tasks, we should control the amount of time a computer is used and take into account other aspects of a child's physiological, intellectual and emotional development (Trageton, 2005).

In pedagogical work, the problems related to the issue of successive learning are commonplace. Those are to be tackled in a theoretical and practical aspect. Preschool teachers are often worried that children have a low level of self-regulation and this prohibits learning written letters and combining them in complete words. In evaluating the basic principles of creating a coherent text in correlation to conscious writing, it should be kept in mind that an artificially created system of word linking cannot form basis of learning to create a coherent text, as because of this system a child does not perceive the meaning of the written word.

This approach may hinder a child's understanding that writing and reading are closely related types of speech activity. Calligraphy as a study subject or as part of language learning to improve handwriting, should take place only at school level, 
and particularly not in the first grade. The first year of school remains a time, when a pupil broadens his or her experience, becomes aware of own skills, realizes what he or she is good at, where he or she should be more attentive. During pre-school and the first year of school a child is not yet ready to perceive and to understand abstract things to consciously use them in communication, therefore an acquisition of the basics of orthoepy and orthography cannot become the most important part of learning contents. (Anspoka, 2011)

During pre-school and early school years a child psychologically is not resultoriented. Yet, a child is willing to engage into a process, and, if a teacher is able to guide this process, in which a child systemically, rather than in a fragmented way, successively and playfully navigates from task to task, and if a teacher appropriately changes the pedagogical means of speech development, a child may indirectly, yet successfully learn many new things and be satisfied about his or her performance.

From a didactical point of view the main goal of pre-school and early school years is to create conditions for a child to be excited, engaged and interested in the learning process and to feel at home in the environment that he or she knows, that interests him or her, so that the work-load and tempo are appropriate for a child's individual capacity.

In a contemporary pedagogical process the quality of gradual development of a child's speech should be viewed as a total of many interrelated factors, preconditions and real actions, in the midst of which each child, regardless what his or her skills are, may demonstrate intellect and willpower. A child gradually becomes accustomed that discovering the world through speech and language is an interesting, yet demanding process that requires becoming stronger in character and more attentive towards language. It is as early as at pre-school that a child needs to realize that language, on the one hand, is a representation of ethnos and culture of individuals and, on the other, language is a means, by which culture is acquired.

\section{Conclusions}

- In contemporary multicultural society one of the most important basic skills to be acquired through a pedagogical process is that of language. This includes a skill to perform speech activities according to the communication situation and to own intentions; a level of language knowledge and techniques that allows using the acquired language purposefully in speech, listening, reading and writing.

- Nowadays every child at pre-school and at early school age requires an individual approach, as each child is at a different level of language and speech development. The reasons for this are to be found in the uneven socio-economic context, in which a child grows and develops. The development of a child's speech is a gradual and natural process that takes 
into account peculiarities of individual development and experience in the use of language.

- Speech development process is an upbringing process of a child's personality. This includes a purposeful discovery of the world, finding a place in this world, a need to find the causality between events and processes, a need to detect correlations between things and phenomena, a need for social interaction, a need to be active, to see results of own work and to receive recognition.

- From the perspective of successive learning it is not acceptable to choose differing language acquisition approaches and topics at pre-school and at early school age that do not deepen the exploration of the world in terms of their form and contents and do not make a child accustomed to thinking in a precise way, to make use of particular language means for the expression of own thoughts. In the development of learning programmes and in preparing study means for a new stage of education, the planned study contents and their level of difficulty should first be carefully assessed, so that a child can perceive and understand the new information by using previously acquired knowledge and skills.

- Given that at pre-school and at early school age a child perceives the world emotionally, it is purposefully planned games and playing that create a positive, free and natural emotional background. A positive study environment also ensures satisfaction of the most important psychological needs - emotional and physical security, close, mutually beneficial relationships, independence, a chance to participate in a process and a conviction that one's knowledge is also useful to others. A child should be sure that he or she would be supported and encouraged if such a need would arise.

- Nowadays it is important that children are in touch with nature. Lessons indoors, with previously prepared natural materials should be supplemented with outdoor classes. Imitative actions play an equally important role in speech development. From the point of successive learning it is only the goal of study content acquisition that is different, as well as its volume and level of complexity, and the proportion of time a child's spends in independent cognition.

- Today information technologies are a great help in the process of a child's speech development. Specially prepared digital learning materials, if used purposefully, enable to use senses (sight, hearing, touch, movement etc.,). Using technology purposefully creates associations with previously acquired experience, and a child notices that just like adults, he or she, too can acquire information by reading or pass it on in writing. 
- From a didactical point of view, the main goal of pre-school and early school stage is to create conditions for a child to be excited, engaged and interested in the learning process and to feel at home in his or her surrounding environment, so that the workload and tempo are appropriate for his or her individual capacity.

\section{References}

1. Anspoka, Z. Rakstpratība pirmskolā un skolā: dažas pēctecības problēmas un risinājumi. Sabiedrïba. Integrācija. Izglïtïba. Rēzeknes Augstskolas starptautiskās zinätniskās konferences materiäli. 2. dala. [Writing Skills At Pre-school and At School: Several Problems and Solutions of Successive Learning. Society. Integration. Education. Rezekne Higher Education Institution, Proceedings of the International Scientific Conference. Part 2.] Rēzekne: RAPSPI, 2011. pp. 21-30. (in Latvian).

2. Dzintere, D., Stangaine, I. (2007) Rotals - beerna dzivesveids. [The Play - A Child's Lifestyle] Rìga: RaKa. (in Latvian).

3. Gavrilina, M., Vulāne, A. (2008). Valodà veldzējas tautas dvēsele. [The Soul of the Nation Revives in Language] Rīga: SIA "Mācību grāmata". (in Latvian).

4. Piažē Ž. (2002) Bèrna intelektuālä attīstïba. [Intelellectual Development of a Child] Rīga: Pētergailis. (in Latvian).

5. Nichols, W., Rupley, W.H, Rasinski, T. (2009). Fluency in Learning to Read for Meaning: Going Beyond Repeated Readings. Literacy Research and Instruction. 48(1). pp. 1-13.

6. Skujin,a, V., Anspoka, Z., Kalnbērzin,a, V., Šalme, A. (2011). Lingvodidaktikas terminu skaidrojošā vārdnica [Dictionary of the Language Learning Methodology Terms]. Rīga: Latviešu valodas aǵentūra, Latviešu valodas institūts, 132 lpp. (in Latvian).

7. Svence, G. (2011). Bērna valodas un runas attīstība pirmsskolas un jaunākajā skolas vecumā. Zinātniski metodisks izdevums TAGAD, 1(6). [Child Language and Speech Development at Pre-school and at Early School Age] (in Latvian).

8. Sousa, A. (2001). How the Brain Learns. 2nd ed. Thousand Oaks: Corvin.

9. Trageton, A. (2005). Creative Writing On Computers: 6- to 10 Year Olds. Writing to Read. In Pandis, Met al: Reading, Writing, Thinking,. Proceedings of the $13^{\text {th }}$ European International Reading Association. Newark. De. USA.

10. Абрамова, Г. С. (2002). Возрастная психология. [Developmental Psychology] Екатенбург: Деловая книга. (in Russian).

11. Амонашвили, С. (2011). Гуманной педагогика. Актуальные вопросы обучения родному языку и развития личности. [Humanist Pedagogy. Topical Questions in Mother-Tongue Education and Personal Development] Москва: Амрита- Русь. (in Russian).

12. Выготский, Л. С. (1997). Вопросы детской психологии. [lssues of Child Psychology] C -Пб.: Сою3. (in Russian). 
13. Крайг, Г. (2000). Психология развития. [Developmental Psychology] СПБ: Питер (in Russian).

14. Новикова, А.М. Методология игровой деятельности. [Methodology of Game Activities] Москва: Издательство «Эгвес», 2006. (in Russian).

Professor, Doctor of pedagogy science (Dr. paed.) Zenta Anspoka Riga Teacher Training and Education Management Academy, Latvia Imantas 7. līnija 1, Riga, phone: +3717808081 , zenta.anspoka@rpiva.lv, phone:+371 29184091 